Saltanat Kuzembayeva

Uniwersytet Warszawski

\title{
Status and prospects of Kazakhstan and the European Union's relations development in the context of the new agreement on cooperation
}

$\mathrm{T}$ he European Union is one of the priorities in the multi-vector policy of Kazakhstan. The significance of relations with the European Union within the integration process was once again confirmed by the adoption of the Enhanced Partnership and Cooperation Agreement (EPCA), signed on December 21, 2015 in the capital of Kazakhstan. Further deepening of the dialogue was initiated by the First President of the Republic of Kazakhstan Nursultan Nazarbayev, who proposed to update the Partnership and Cooperation Agreement of 1995 during a meeting with the European Commission President Jose-Manuel Barroso in December 2006 in Brussels. The Ministry of Foreign Affairs of the Republic of Kazakhstan together with the relevant state bodies in November 2008 prepared a concept for a new treaty that accelerated the start of relevant negotiations in order to support the initiative on the need for an expanded format agreement. The simultaneous launch of the state program Way to Europe, which was positively assessed by the Europeans, contributed to the chairmanship of Kazakhstan in the OSCE in 2010. However, despite the success, significantly strengthening the position of the state in Europe and the region, the active stage of negotiations fell on the period from 2011 and ended in 2014. As a result, the draft agreement was initialed on January 20, 2015 in Brussels, and the Kazakh parliament ratified it in March 2016.

All the EU member states and the European Parliament ratified the EPCA. It became an expression of the desire to deepen cooperation in three main areas that determine the special role of Kazakhstan in the EU relations with the Central Asian region. The EPCA means political dialogue in the field of foreign policy and security, economic and industry cooperation. An extended format agreement includes issues of control over the fulfillment of the terms of the agreement that were absent in the previous agreement. The EPCA's entry into force on March 1, 2020 helps to strengthen cooperation in areas that earlier were not subjected to the agreement. In this regard, at the inter-parliamentary level there were created institutions with the purpose to form the necessary conditions for the full use of the potential 
of this expanded partnership in practice. However, it should be noted that in order to achieve the objectives of the Treaty, the parties have established authorized bodies: the Cooperation Council, the Cooperation Committee and specialized subcommittees. The activities of the bodies are aimed at the development of parliamentary cooperation between the European Parliament and the Parliament of the Republic of Kazakhstan (Senate and Majilis). One of the first Meetings of the Subcommittee on Customs Cooperation between Kazakhstan and the European Union (Zakon.kz, 2013) was held at the Ministry of Foreign Affairs of the Republic of Kazakhstan, where the parties discussed the organizational issues of the subcommittee's work and identified areas for further cooperation.

The EU considers that the new expanded cooperation means strengthening political relations and stimulating democratic processes in the Republic of Kazakhstan, which will result in the country's long-term stability and its development. Kazakhstan, in turn, expects to gain greater international recognition and expanded access to the European market. The Kazakhstan side could not ignore the fact that the EU is its largest trade and economic partner. In the total volume of foreign trade turnover represents more than a half of direct foreign investment in Kazakhstan. By means of the EPCA, the EU and Kazakhstan have laid the framework for further strengthening trade and economic relations.

\section{Effects of the Agreement's Implementation in 2016-2018}

Due to the growing influence of China and Russia's attempts to maintain influence in the region, it is difficult to determine how and to what extent the EU will exert its geopolitical influence. In addition, it is difficult to fully assess what the main shifts in the Kazakhstan-EU relations are for the period under review, because bilateral dialogue goes beyond the framework of the EPCA. However, the EU is a valuable partner, promoting regional cooperation as an alternative to the significant influence of Russia and China. In general, Kazakhstan is interested in the joint work with the EU both through the EPCA and through the new EU-Central Asia Strategy for 2019 at the regional level. The greatest bilateral interest of Kazakhstan is related to the European investments and trade, cooperation in the field of education and institutional development. The EU is also interested in expanding trade and plays a stabilizing role in Central Asia. Due to the possibility of influence in the region, the EU can use advantage to successfully pursue an active democratic policy, which is clearly determined by the adoption of the New EU Strategy - Central Asia 2019 (CAAN, 2019). Recent modernization efforts in the region have led to deeper cooperation with the EU in economic diversification by launching three large-scale programs with a total budget of 28 
million euros for the prosperity of Central Asia (Official website of the European Union, 2019). The official signing ceremony of the three agreements for the three programs was held as part of the international conference on the theme "Strengthening Integration for Prosperity in Central Asia" in the capital of Kazakhstan. The programs will start at the beginning of next year and will be implemented within the framework of the new EU Strategy for Central Asia, which was adopted in June 2019 (Inbusiness.kz, 2019). The growing interest of Europeans in the economy of Kazakhstan is due to structural changes in the investment policy in the country aimed at effective investment, which in turn led to an increase in trade between the parties to the agreement. According to the data of the State Revenue Committee of the Ministry of Finance of the Republic of Kazakhstan for 9 months of 2018, mutual trade between the Republic of Kazakhstan and the EU amounted to 28.6 billion US dollars; it is $30 \%$ higher than the volume of foreign trade turnover in 2017 (\$22 billion). Foreign trade of Kazakhstan with the EU accounts for $41.9 \%$ of the total trade volume (68.2 billion US dollars). The EU share has been growing for the last two years (in 2016 it was 38.4\%) (Zakon.kz, 2018). According to the statistics of the National Bank of the Republic of Kazakhstan for 2016, the gross inflow of direct investments from the EU amounted to 10.794.4 billion US dollars. It is $52.3 \%$ of the total volume of investments attracted to the economy of the Republic of Kazakhstan in 2016 (Официальный сайт Правительства Республики Казахстан, 2019); it indicates a positive balance sheet for Kazakhstan in trade with the EU.

Further progress in the area of economic cooperation between the EU and Kazakhstan depended largely on the accession of Kazakhstan to the World Trade Organization (WTO) (Tengrinews, 2015). Kazakhstan is deeply involved in the processes of economic integration as a member of the Eurasian Economic Union, and at the same time it is a state that plays a significant role in individual world markets as a member of the WTO. A key factor in the formation of trade and the strengthening of economic assistance between Kazakhstan and the EU is the facilitation of visa procedures. The abolition of the visa regime has become one of the main topics in further negotiations between the parties. In turn, Kazakhstan on July 15, 2014 unilaterally confirmed a visa-free regime for citizens of $10 \mathrm{EU}$ countries, which are the largest investors in the country, and from January 1, 2017, the visa regime for citizens of Poland was lifted. This is of particular importance for Poland, which among the EU member states is the seventh importer from Kazakhstan and the fifth exporter to this country. In the future, it would help in cooperation with international partners to prevent crisis situations and eliminate their consequences, as well as to overcome global challenges in the field of energy 
security and diversification of energy sources. Kazakhstan has significant energy resources such as oil, natural gas and coal; the country is one of the main producers of uranium (World Nuclear Association, 2020). It should be noted that, being a member of the Customs Union, the republic is one of the most economically oriented to the EU post-Soviet states, and this trend (unlike most other post-Soviet states) is more likely to grow, rather than weaken. However, the sanctions imposed by the West on Russia and the global crisis negatively affected the economy of Kazakhstan. In order to promote energy cooperation with the countries of the European Union, the country needs an alternative route for transporting oil. This is the project for the construction of the Kazakhstan Caspian transport system. Negotiations on the project were conducted in 2007-2009, but were abandoned due to the unpreparedness of the Kashagan field for operation. New geopolitical conditions (unstable situation in Ukraine) forced the authorities to return to the idea of building the Kazakhstan Caspian transport system laid in Turkey (ROGTEC, 2016). Turkey, due to its location between the eastern and western markets, easy access to the European market and cultural proximity, is also a major investor in Kazakhstan. As it was mentioned above, Kazakhstan needs alternative partners for foreign investment. The Nur-Sultan authorities consider cooperation with China to be one of such priority areas. China's One Belt, One Way Initiative creates new perspective in Central Asia. Europe and China are involved in using the initiative to develop their economy, since China nowadays is the world leader in the country's commodity circulation, the EU member states are also interested in laying new routes. In order to attract investment from China to the development of transport infrastructure, Kazakhstan is no less interested in cooperation under this initiative, since it is the central country for China's land route. In addition, relations with the states of East Asia and Western Europe have gained unprecedented importance, which for each of the parties is a prospect in the transport and logistics sphere connecting Europe with Asia. The geopolitical location of Kazakhstan contributed to the rapprochement of the positions of the parties on a number of foreign policy, trade and economic issues. The transit routes of Western China and Europe are a great example. In the new project, Kazakhstan was named a key region in the interaction of East and West. At the same time, large-scale projects are underway to optimize and diversify transport directions. For example, in September 2016 a new container service was launched in transcontinental transport between China and Europe via Urumqi (China) - Altynkol (Kazakhstan) - Riga (Latvia) - Rotterdam (Netherlands), which opens the door to the largest seaport in Europe and can lead to a significant increase in the volume of commodity circulation of Kazakhstan with a number of the European states. In particular, according to 
experts, the new transit will twice increase the turnover with Latvia (The Baltic course, 2017). Thus, the intensification of the dialogue with the EU countries has become relevant. The consistent implementation of the new agreement allowed us to increase the volume of trade, primarily through trade in high-tech products, to generate new opportunities for economic growth and job creation.

\section{Development Prospects of the relations between Kazakhstan and the European Union}

Undoubtedly, the Enhanced Partnership and Cooperation Agreement (EPCA) between Kazakhstan and the European Union, temporarily and partially applied since May 2016, has already contributed to strengthen bilateral relations. This is evidenced by the data of the Ministry of National Economy of the Republic of Kazakhstan, which reached the highest direct investment from the EU in 2016 (10.8 billion dollars), it is more than a half of the total volume of attracted investments in Kazakhstan. However, it is obviously that political stability is one of the key factors affecting the investment attractiveness of the economy. Due to the unprecedented for modern Kazakhstan increase in protest actions and conflict situations in 2018, almost half of the EU countries reduced investment in the state's economy (Ranking.kz, 2019). Therefore, the further effective participation of Kazakhstan in the implementation of the European development programs within the framework of the new EPCA can become one of the important tools for ensuring sustainable state's development. Thus, in the near-term Kazakhstan-EU relations, the two hypothetical scenarios can be suggested. The key factor that would allow the positive scenario to come true is a change in thinking in Nur Sultan. In other way, any reforms will not be able to guarantee successful mutually beneficial relations. However, the practical implementation of this scenario is extremely unlikely, since the main task of the government is still ensuring compliance with the agreement, which will require the adoption of the bulk of legislation through parliament, as well as significant institutional changes. This problem can be solved by introducing new systems into the government mechanism to ensure regular monitoring of the implementation of the EPCA. Achieving a deeper level of relations will necessarily require Kazakhstan's commitment to promoting democratic values and gradual political reforms towards good governance, respect for human rights and the creation of a multi-party system with truly free elections. The EU will need active support for the protection and implementation of fundamental freedoms in Kazakhstan, as well as facilitating an open and constructive political dialogue, and therefore the real impact of the agreement in this sense remains to be assessed. In addition, questions regarding calls for election transparency, freedom of speech, trade 
union and civil society independence are still relevant. The European Parliament emphasized that the implementation of the EPCA should be subordinated to an "effective monitoring mechanism based on clear benchmarks and timelines" (European Parliament, 2017), not only in the economic sphere, but also in terms of democratic development and human rights. The EU should closely monitor and support (through capacity building projects) the implementation of Kazakhstan in its national reform plans, with specific reference to the provisions set out in the PCRS.

The most likely scenario, according to the author of this article, is to keep the current level of bilateral relations, since Nur-Sultan has not yet shown its readiness to change its line. Economic interdependence will continue to play a stabilizing role. Political rapprochement with the European Union while maintaining economic interdependence would allow the European Union to form a coherent political and economic agenda and policies for Kazakhstan, as well as significantly strengthen its influence. At the same time conducting commercial relations and switching to the trade basis of the foreign policy of the EU countries and supporting Kazakhstan's WTO membership, as well as the economic priorities of individual EU countries, often prevail over common interests. This tendency in principle meets the interests of Kazakhstan, which has traditionally emphasized the economic component of partnership and bilateral relations with the EU countries. Therefore, the scenario that is currently being implemented by the Kazakhstani leadership is a close economic interaction without political obligations. Its essence is to combine economic openness in relation to the European Union, which is important for maintaining the market economy and attracting investments, ignoring criticisms from it, threatening the stability of the Kazakhstani political system with its limited competition and the absence of stable institutions.

\section{Conclusion}

Despite a large number of potential points of contact in the region for trade and economic interaction between Kazakhstan and the EU, there are some restrictions influencing the situation. In this context, it is worth noting the participation of Kazakhstan in other regional integrations. Kazakhstan considers its partners not only the states of the European Union, but also Russia, China, the United States and Turkey, and the cooperation with them is in economic and political priority, which corresponds to the parameters indicated by the Concept of the Republic of Kazakhstan's Foreign Policy for 2014-2020 (Официальный сайт Правительства Республики Казахстан, 2014). The European integration projects risk being 
frustrated by the regional realities. In its quest to deepen relations with Kazakhstan, the EU is competing with Russia and China. Compared to Brussels, which sees reform as a necessary condition for economic and political reward, neither Moscow nor Beijing are asking Kazakh politicians to liberalize in exchange for their support. While Russian and Chinese officials focus solely on business transactions or security cooperation, the EU cooperation is often accompanied by certain conditions. Ultimately, the country's institutional backwardness is still the main obstacle to further deepening bilateral relations. In this regard, Kazakhstan's current efforts to strengthen accountability, the rule of law and good governance should strengthen relations between the EU and Kazakhstan more than any formal agreement.

\section{Streszczenie}

W artykule przeanalizowano skutki wdrożenia Umowy o wzmocnionym partnerstwie i współpracy (SPS) między Kazachstanem a Unią Europejską, której celem jest wykazanie wzajemnej woli politycznej $\mathrm{w}$ celu rozszerzenia strategii współpracy na poszerzone partnerstwo. Stosunki dwustronne są rozpatrywane w następujących aspektach: dialog polityczny $\mathrm{w}$ dziedzinie polityki zagranicznej i bezpieczeństwa; współpraca gospodarcza i przemysłowa. Jednocześnie omawiane są długoterminowe perspektywy i możliwe scenariusze dalszego rozwoju stosunków dwustronnych, a także zagrożenia, z którymi może się zmagać Kazachstan, tworząc swój „wektor europejski” dzięki zastosowaniu SPS w ramach Kazachstanu prawo i porządek.

\section{Słowa kluczowe:}

Wspólnota Niepodległych Państw, Eurazjatycka Unia Gospodarcza, Światowa Organizacja Handlu.

\section{Key words:}

Commonwealth of Independent States, Eurasian Economic Union, World Trade Organization.

\section{Bibliografia:}

1. EU Regional Conference on Enhanced Integration for Prosperity in Central Asia kicked off today in Nur-Sultan (2019). Official website of the European Union: https://eeas.europa.eu/delegations/uzbekistan/71162/eu-regional-conferenceenhanced-integration-prosperity-central-asia-kicked-today-nur-sultan_en

2. Report containing a motion for a non-legislative resolution on the draft Council decision on the conclusion, on behalf of the Union, of the Enhanced Partnership and Cooperation Agreement between the European Union and its Member States, of the one part, and the Republic of Kazakhstan, of the other part, (12409/2016 - C80469/2016 - 2016/0166(NLE) - 2017/2035(INI)). European Parliament, Committee 
on Foreign Affairs (2017): http://www.europarl.europa.eu/sides/getDoc.do?pubRef=//EP//NONSGML+REPORT+A8-2017-0335+0+DOC+PDF+V0//EN

3. Kazakhstan Caspian Transport System Needed After Kashagan Restart? ROGTEC (2016): https://rogtecmagazine.com/kazakhstan-caspian-transport-system-neededkashagan-restart/

4. Uranium and Nuclear Power in Kazakhstan (2020). World Nuclear Association: http://www.world-nuclear.org/information-library/country-profiles/countries-g$\mathrm{n} /$ kazakhstan.aspx

5. В Рижский порт едет первый контейнерный поезд Урумчи-Роттердам (2017). The Baltic course: http://www.baltic-course.com/rus/good_for_business/?doc=134024

6. Валовой приток прямых иностранных инвестиций в Казахстан по итогам 2018 года (2019). Ranking.kz: http://ranking.kz/ru/a/rankings/v-2018-godu-pochtipolovina-stran-es-sokratila-investicii-v-ekonomiku-kazahstana-obshee-snizhenievalovogo-pritoka-pii-po-etim-stranam-sostavilo-122

7. Евросоюз выделит 28 миллионов евро для реализации трех программ в ЦА (2019). Inbusiness.kz: https://inbusiness.kz/ru/last/evrosoyuz-vydelit-28-millionovevro-dlya-realizacii-treh-programm-v-centralnoj-azii? fbclid=IwAR33jSYc3WrWfSn9PUK6e_O6cKV1eEmz2udPrHtqIbtVsqptVEv4f5up4k

8. Казахстан и ЕС: Торгово-экономическое сотрудничество (2019). Официальный сайт Правительства Республики Казахстан: http://www.mfa.gov.kz/ru/brussels/content-view/kazakhstan-eu

9. Казахстан официально вступил в ВТО (2015). Tengrinews: https://tengrinews.kz/kazakhstan_news/kazahstan-ofitsialno-vstupil-v-vto-278365/

10. Концепция внешней политики РК на 2014-2020 гг. (2014). Официальный сайт Правительства Республики Казахстан: http://mfa.gov.kz/ru/erevan/contentview/koncepcia-vnesnej-politiki-rk-na-2014-2020-gg

11. Новая стратегия ЕС по усилению взаимосвязанности в Центральной Азии и ее вызовы (2019). CAAN: https://caa-network.org/archives/16304

12. Стратегическое партнёрство ЕС с Казахстаном укрепляется: товарооборот вырос на 30\%, до 28,6 миллиарда долларов США за три квартала 2018 года (2018). Zakon.kz: https://www.zakon.kz/4946687-strategicheskoe-partnerstvo-ess.html

13. 28 марта 2017 года в Министерстве иностранных дел РК состоялось 1-ое заседание Подкомитета по таможенному сотрудничеству Казахстана и Европейского союза (2017). Zakon.kz: https://www.zakon.kz/4851175-28-marta2017-goda-v-ministerstve.html 